\title{
CHIARITÉ
}

UNIVERSITÄTSMEDIZIN BERLIN

\section{The German Health Care Innovation Fund - An Incentive for Innovations to Promote the Integration of Health Care}

Anne Berghöfer, Denes Göckler, Jörg Sydow, Carolin Auschra, Lauri Wessel, Martin Gersch

\author{
Document type \\ Postprint (accepted version)
}

This version is available at

https://doi.org/10.17169/refubium-28842

\section{Citation details}

Berghöfer A, Göckler DG, Sydow J, Auschra C, Wessel L, Gersch M. The German health care Innovation Fund - An incentive for innovations to promote the integration of health care. Journal of Health Organization and Management. [Online] Emerald; 2020;34(8): 915-923.

DOI: 10.1108/jhom-05-2020-0180

\section{Terms of use}

This work is licensed under a Creative Commons Attribution-NonCommercial 4.0 International license: https://creativecommons.org/licenses/by-nc/4.0/

This means that anyone may distribute, adapt, and build upon the work for non-commercial purposes, subject to full attribution. If you wish to use this manuscript for commercial purposes, please contact permissions@emerald.com. 


\section{The German health care Innovation Fund - An incentive for innovations to promote the integration of health care}

Anne Berghöfer, Priv.-Doz. Dr. med., Institute for Social Medicine, Epidemiology and Health Economics, Charité - Universitätsmedizin Berlin, Luisenstr. 57, 10117 Berlin, Germany. anne.berghoefer@charite.de (corresponding author)

Denes Göckler, M.Sc., Master Studies Management and Quality Development in Health Care, Alice Salomon Hochschule Berlin, Germany. denes.goeckler@web.de Jörg Sydow, Prof. Dr., School of Business \& Economics, Department of Management, Freie Universität Berlin, Germany. Joerg.Sydow@fu-berlin.de

Carolin Auschra, Dr., School of Business \& Economics, Department of Management, Freie Universität Berlin, Germany. Carolin.Auschra@fu-berlin.de

Lauri Wessel

European New School of Digital Studies, European University Viadrina, Frankfurt (Oder), Germany

Martin Gersch, Prof. Dr., School of Business \& Economics, Department of Information Systems, Freie Universität Berlin, Germany. martin.gersch@fu-berlin.de

Corresponding author:

Priv.-Doz. Dr. med. Anne Berghöfer Institute for Social Medicine, Epidemiology and Health Economics

Charité - Universitätsmedizin Berlin Luisenstr. 57, 10117 Berlin, Germany anne.berghoefer@charite.de 


\title{
The German Health Care Innovation Fund -
}

\section{An Incentive for Innovations to Promote the Integration of Health Care}

\begin{abstract}
Purpose - Many health systems face challenges such as rising costs and lacking quality, both of which can be addressed by improving the integration of different health care sectors and professions. The purpose of this viewpoint is to present the German health care Innovation Fund (IF) initiated by the Federal Government to support the development and diffusion of integrated health care.

Design/methodology/approach - This article describes the design and rationale of the IF in detail and provides first insights into its limitations, acceptance and implementation by relevant stakeholders.
\end{abstract}

Findings - In its first period, the IF offered $€ 1.2$ billion as start-up funding for model implementation and evaluation over a period of four years (2016-2019). This period was recently extended to a second round until 2024 , offering $€ 200$ million a year as from 2020. The IF is triggering the support of relevant insurers for the development of new integrated care models. In addition, strict evaluation requirements have led to a large number of health service research projects which assess structural and process improvements and thus enable evidence-based policy decisions.

Originality/value - This article is the first of its kind to present the German IF to the international readership. The IF is a political initiative through which to foster innovations and promote integrated health care.

Key words Innovation Fund; integrated care; reform initiatives; policy instrument; statutory sickness funds; health service research; Germany

Paper type Viewpoint 


\section{Introduction - The German Health Care Innovation Fund in the Context of Long- standing Health Care Reforms in Germany}

Due to the aging population and the increasing prevalence of chronic diseases and multiple co-morbidities, most Western governments seek to adapt health care by integrating services across the primary, secondary, and home care sectors and across health care professions (Busse and Stahl, 2014). Integrated care (IC) is meant to secure continuity, coordination, and appropriateness of health and health-related social services and thus increase quality and efficiency of care and satisfaction of users. IC can include a variety of services and providers to varying degrees, encompassing cure and care, integrating administrative and organizational issues up to a joint financing (Kodner and Spreeuwenberg, 2002). IC is therefore particularly suitable for the care of an aging population.

Policy initiatives to foster IC have consumed noteworthy resources and lessons learned are that the national government, regional and local authorities should proactively set the agenda and encourage initiatives rather than leaving integration to the market (Mur-Veeman et al., 2008). Germany is a case in point, but the impact of a series of reforms that were introduced over the last two decades is generally seen as falling behind expectations (Schlette et al., 2009) [see figure 1]. While there is no shortage of product innovations in the German health care sector, mainly as a result of major investment by manufacturers, hardly any structural or process innovations have taken place. The health system as a whole is characterised not only by institutional complexities and persistence, but even by path dependencies which make disruptive innovations (Christensen et al., 2015) that would lead to significant system changes practically impossible (Sydow et al., 2009, Auschra and Sydow, 2020). Thus, the German social security system (see Obermann et al., 2019, Busse et al., 2017 for 
details about the basic structure of the German health care system), which provides the financial foundation of most health care services in this country, is characterized by reactive behaviour towards inter-/cross-sectoral challenges. Because Germany lacks a structure at the federal level that sets binding strategic guidelines for the entire health care system, the steering power of the national policy is weak, and there is no consensus on more far-reaching agreements on change that can be implemented by the actors in a structured process, as is indeed possible in countries with a state health care system (Gilbert et al., 2015).

Since 2000 , the legislator has been trying to create targeted incentives to open the health care system to new forms of cooperation, delegation and digitalization, the latter in particular being associated with a development towards more integrated care (Lluch and Abadie, 2013). Initial policy initiatives included financial incentives for statutory sickness funds (SSFs) to develop disease management and IC (Health Care Modernization Act, 2004; Greb et al., 2006). Along with mildly competitive conditions to which SSFs have been subjected by politics (Thomson et al., 2013, Göpffarth and Henke, 2013), political initiatives are more likely to result in incremental innovations which remain limited to companies and service areas, thus having no effect on the system as a whole (Gibis and Steiner, 2014).

The lack of a widespread implementation of IC in Germany led to a new legal initiative in form of the Innovation Fund (IF). The aim of this viewpoint is to introduce the IF as a policy instrument, and to outline its effectiveness on fostering integrated care, its limitations, and its reception to the international reader.

\section{Design of the Innovation Fund}

In 2015, the German parliament passed the Health Care Strengthening Act (GKVVersorgungsstärkungsgesetz; Milstein and Blankart, 2016), primarily aiming at 
lowering costs and/or improving the quality of care by means of better integration, mainly across manifested sectors of health care (primary, secondary, home care) as well as health care professions. A key instrument to help implement the objective of the bill is the Innovation Fund (IF) (§§ 92a-92b Social Insurance Code Book V). The IF provided start-up funding for IC models and evaluating health service research to the value of $€ 300$ million per year for a period between 2016 and 2019 (see Table 1 for details; Amelung et al., 2017, Gemeinsamer Bundesausschuss, 2020b). For a second period, 2000 until 2024, the IF continued with funding of $€ 200$ million p.a. up. The IF thus has incentivized - and continuous to do so - service providers, statutory sickness funds, and researchers to develop, implement and diffuse IC. After funding disease management and financing the start-up of IC (Greb et al., 2006), the IF is now the third major political initiative that aims to foster innovations in the health care system [see figure 1] within the last two decades. The present IF incorporates some important learnings from the rather modest success of the two former initiatives.

To some extent, the IF resembles an instrument that was implemented as part of an earlier health reform (Health Care Modernization Act, 2004; Greb et al., 2006), in which start-up funds were only provided for IC. However, there are important differences between the two funding schemes: firstly, the body that decides on the provision of funding differs (from 2004-2008 the statutory sickness funds were in charge); secondly, the projects of the IF must have the potential for scaling, and the scientific evaluation of projects is now mandatory. 
Figure 1: Selection of German health care system reforms associated with the fostering of integrated care, innovation and digitalisation in health care between 2000 to 2020

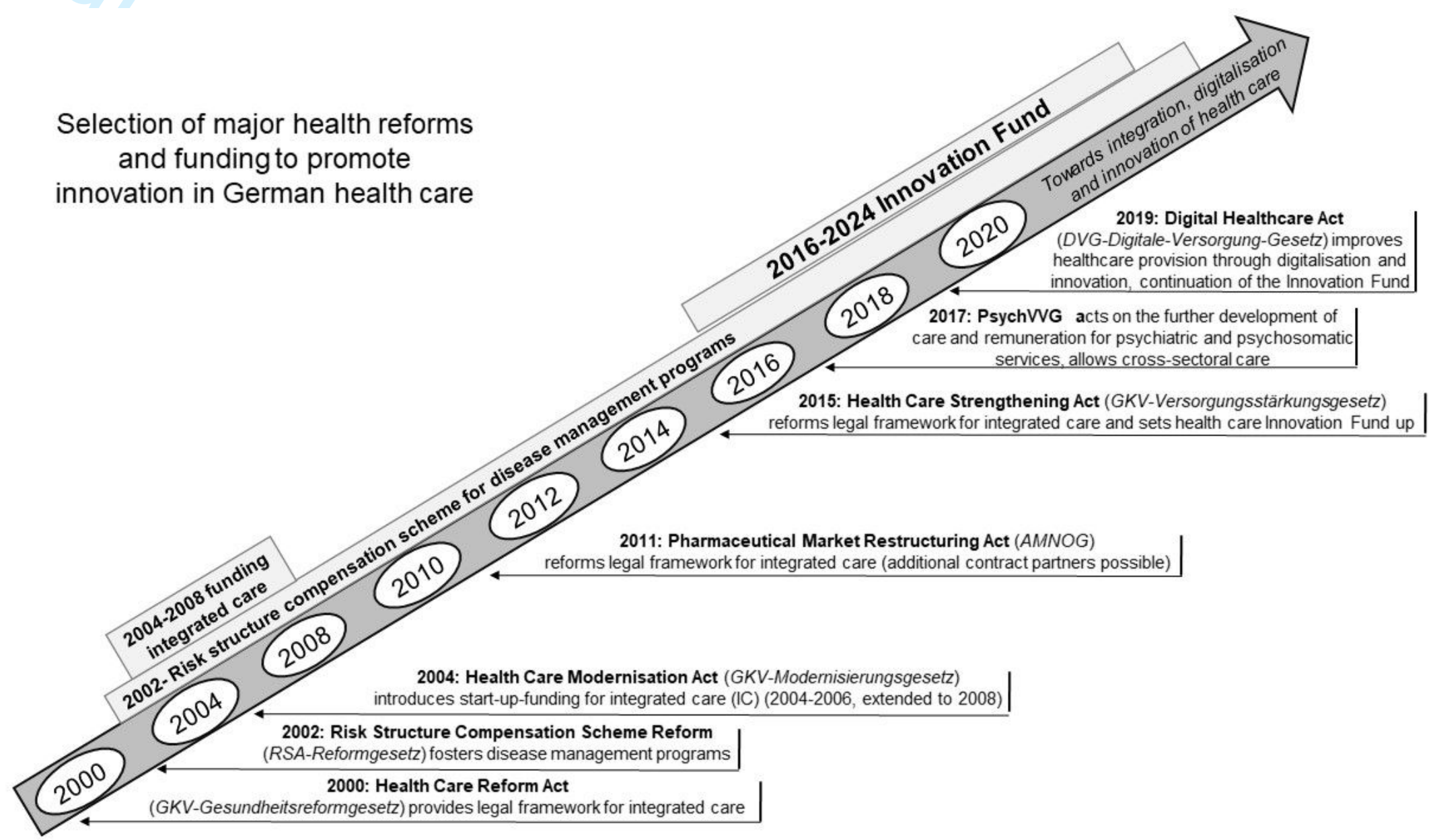


Table 1: Content and procedure of the German heath care Innovation Fund.

\begin{tabular}{|c|c|}
\hline $\begin{array}{l}\text { Funding } \\
\text { volume }\end{array}$ & $\begin{array}{l}€ 300 \text { million per year over the first funding period of four years } \\
(2016-2019) \text {, of which } € 225 \text { million were for developing integrated } \\
\text { health care models including their evaluation, and } € 75 \text { million for } \\
\text { outcomes and health service research projects; } \\
€ 200 \text { million per year over the second funding period of five years } \\
(2020-2024) \text {, of which } € 160 \text { million are for models, } € 40 \text { for health } \\
\text { service research }\end{array}$ \\
\hline $\begin{array}{l}\text { Funding } \\
\text { source }\end{array}$ & $\begin{array}{l}\text { German statutory sickness funds and German Central Health Fund } \\
\text { (Gesundheitsfonds) }\end{array}$ \\
\hline $\begin{array}{l}\text { Funding } \\
\text { require- } \\
\text { ments }\end{array}$ & $\begin{array}{l}\text { Innovative models of health care should } \\
\text { - be above the level of standard care provided presently by the } \\
\text { statutory sickness funds } \\
\text { - improve cross-sectoral collaboration } \\
\text { - reduce intra- and inter-sectoral fragmentation } \\
\text { - involve given subject areas (e.g. telemedicine, geriatric care, the } \\
\text { provision of care in rural areas, drug safety for multi-morbid } \\
\text { patients) } \\
\text { - include the evaluation of the outcome of treatment } \\
\text { - have potential for scaling into standard care and its implementation } \\
\text { - be supported by at least one statutory sickness fund as a } \\
\text { consortium or cooperating partner } \\
\text { - project the duration, with a maximum funding period of } 3.5 \text { years }\end{array}$ \\
\hline $\begin{array}{l}\text { Time } \\
\text { schedule }\end{array}$ & $\begin{array}{l}\text { Regular calls (April 2016, May 2016, February 2017, October 2018, } \\
\text { December } 2019, \text { to be continued annually) }\end{array}$ \\
\hline $\begin{array}{l}\text { Code of } \\
\text { procedure }\end{array}$ & $\begin{array}{l}\text { - Decisions on grants are made by the Innovation Committee, a } \\
\text { subcommittee of the Joint Federal Committee (Gemeinsamer } \\
\text { Bundesausschuss), consisting of ten members who represent } \\
\text { providers, payers, and government officials of the Federal Ministry of } \\
\text { Health and the Federal Ministry of Education and Research. } \\
\text { - Advisory board of experts from academia and care providers } \\
\text { review grant applications and recommend funding } \\
\text { - Project supervision by the DLR (German Aerospace Center) } \\
\text { project management agency }\end{array}$ \\
\hline
\end{tabular}

\section{Effectiveness of the Innovation Fund on Integrated Care Initiatives}

\section{Funded Projects of Integrated Care}

To date, a total of 551 health care models and 913 health service research projects have been applied for, 380 have been funded with a total of 1,056.6 million Euro (Gemeinsamer Bundesausschuss, 2020b). Overall 150 positive decisions were made on applications that promote integrated care within health care. These IC models differ 
greatly in terms of the breadth of integration (e.g. defined clinical groups, SSFs participating, or a circumscribed region), the depth of integration (number of sectors, number of professions), and the financial and organisational integration (from joint organisation to complete budget responsibility). None of the models works at a population level yet. Besides IC, a second focus of the funded models was on health care innovations to improve health care in rural or in structurally weak regions. Beyond this, various models aim to develop digital solutions in health care and foster digital infrastructure such as telemedical cooperation networks, electronic medical records or teleconsultations.

Overall 230 health service research projects were funded, a substantial number of which dealt with quality assurance and improvement in health care and with the advancement of patient safety. In addition, studies addressed needs-based health care and efficiency of health care within the SSF-system. They examined the use and linking of routine data to improve care as well as the linking of health data at patient and population level.

In view of several calls the framework conditions and processes of the IF have been firmly established. Based on the recommendations of the advisory board of experts (Blettner et al., 2018) and a formalised and competitive application procedure, there was an incentive to develop study protocols that could be published internationally (Kuss et al., 2018, Koch et al., 2018). The first five projects in the area of health services research have been completed and the results, including recommendations for the transfer of findings to standard care, were published by the Innovation Committee (Gemeinsamer Bundesausschuss, 2020a). 


\section{Stakeholders Perspective on the Innovation Funds}

While there is an obligation to evaluate the IC models funded by the IF to generate evidence of effectiveness, the IF itself is accompanied by way of three assessment studies. A first (Delphi-) study, which aimed to capture the perspective of the many stakeholders involved, included representation from SSFs, health and research policy, patient representatives, healthcare providers, and scientists. It explored the perspective of the stakeholders to recommend how the Innovation Committee should allocate funds effectively, efficiently, justly, transparently and sustainably (Schmitt et al., 2015).

A second study to assess the fund as a policy instrument as such was initiated by the legislative body itself. An interim report was published in 2019 for the German Federal Parliament (Die Bundesregierung der Bundesrepublik Deutschland, 2019) to provide parliamentarians with a basis on which to decide whether or not to extend the Fund. The report identified that the main disadvantage of the IF was the uncertainty that successful models and projects would be incorporated into regular care. On the one hand, a structured process of how to do this has not been legally anchored; on the other hand, the funding decisions are made by the representatives of the established associations. This harbours the danger that decision-makers might place association policy calculations above the evidence generated in the model evaluations and thus render the introduction of potentially disruptive innovations into the health care system unlikely, if not impossible. There was also criticism that IC models were only developed within the health care system, and not being incorporated into other social insurance code books such as social welfare. The evaluation identified that insufficient flexibility was available for projects during their funding period, necessitating considerable administrative effort. The report therefore recommended for the second funding period that stakeholders from outside the health care self-governance system should be 
included in order to structure the transfer process into routine care, to enhance transparency of the peer-review and decision process of the applications, and to strengthen the focus on non-physician professions according to their role in the health care system and support their applications (Die Bundesregierung der Bundesrepublik Deutschland, 2019). Indeed, the second funding period of the IF began in 2020 with a consultation process initiated publicly by the Innovation Committee and addressing various stakeholders, in addition, a pool of experts was formed (Gemeinsamer Bundesausschuss, 2020a).

The third, a process study, which accompanied the legislative initiatives with three cross-sectional surveys, captured how the SSFs engaged in and appraised IC within the framework of new legislation (Göckler, 2017, Gersch et al., 2012, Gersch et al., 2010). Predominant reasons for submitting proposals to the IF were improving the quality and efficiency of care. Large SSFs (> 1 million insured persons) in contrast to small SSFs evaluated the IF as being useful for innovation generation and to foster digitalization of health care. SSF representatives, nevertheless, complained of the low transparency of the application process fearing that political influence could be concealed behind a non-transparent decision-making process as the reviews of the external referees were not communicated. Writing a proposal was considered to be challenging, and the effort required for developing an evaluation concept and coordinating with health care providers as well as the application was rated as being high (Göckler, 2017). Since only some of the 113 health insurance funds existing in 2017 participated, a bias towards the participation of those funds active in IC cannot be ruled out. 


\section{Discussion - The Effectiveness of German Legal Measures to Strengthen Integrated Health Care}

Not many of the IC models in the start-up funding period between 2004 and 2008 proved to be sustainable, as many lacked a sustainable business model for the time after the start-up funding (Amelung et al., 2015). Other IC contracts seem to have served as a legitimacy façade to get money back that was mandated to the start-up financing (Auschra, 2017). In addition, the initially lacking scientific evaluation of the models limited the long-term effect of this policy instrument as well. In sum, the significance of IC continued to be negligible for SSFs (below $1 \%$ of the yearly budget), and only few of them engaged in IC.

The IF, in contrast, provides incentives to develop a large number of IC models and serves as an impulse for SSFs to engage and to collaborate with health service providers. The broad scope of the funding conditions leads to new developments not only in the field of IC, but also beyond it in the areas of digitalisation, health care coverage or quality of care, and thus exerts a more general innovation-promoting effect.

Secondly, the linking of a funding approval with the potential for scaling up to standard care should ensure significantly more sustainability in the design of the IC models. However, this remains unclear once the IF comes to an end, because a structured transfer process into routine care does not yet exist. As long as the Innovation Committee does not pass regulation to that effect, the SSFs de facto decide on any interim financing of a model which was positively evaluated or a model must be costly rebuilt to the original standard care (Reinhardt, 2018).

Thirdly, the IF provides for a mandatory evaluation of all new models and thus for the first time promotes the generation of evidence in health care research, a novelty in the context of legislative initiatives in Germany. However, the need for positive evaluation 
for upscaling into standard care might put pressure on the evaluators and could thus undermine scientific neutrality.

The IF might not support the dissemination of disruptive innovations though (Kleinke et al., 2009). Instead, the IF may only add to the scaling of previously developed prototypes, thereby favouring incremental innovations, driven by a few very committed active SSFs which, however, are continuously growing in number (Gersch and Sydow, 2017).

The IF's innovation effect could possibly be better exploited if all applications, including those that were rejected, were made public. The same applies to the peer review of all applications and the decision history and discussion in the Innovation Committee on which approval or rejection is based. The abundance of applications to the IF contains much more innovative potential if the rejected models are considered as well (Stegmaier and Roski, 2019).

\section{Conclusions and Policy Implications}

The IF is an example of decisive legislative action to promote integration in a health care system which, due to its self-governing structure in Germany, tends to be rather persistent and less effective in promoting innovation than centrally managed health care systems. Thus, lessons learned from its effects, acceptance, and limitations are of interest to all health care systems that are characterized by self-administration structures and a multitude of stakeholders involved in provision of health care, such as countries with Bismarck-type health care systems or the USA.

The accompanying assessments of the IF shows, that first, a policy instrument such as funding innovation should rely on a transparent application process. Second, the effort required for funding application ought to be simplified. Third, mandatory 


\section{evaluation seems helpful to create a national knowledge base on the effectiveness and}

\section{efficiency of IC models.}

\section{References}

AMELUNG, V., WOLF, S., OZEGOWSKI, S., EBLE, S., HILDEBRANDT, H., KNIEPS, F., LAGEL, R., SCHLENKER, R. U. \& SJUTS, R. 2015. [Declared dead? Recommendations regarding integrated care from the perspective of German statutory health insurance]. Bundesgesundheitsblatt Gesundheitsforschung Gesundheitsschutz, 58, 352-9.

AMELUNG, V. E., EBLE, S., HILDEBRANDT, H., KNIEPS, F., LÄGEL, R., OZEGOWSKI, S., SCHLENKER, R.-U. \& SJUTS, R. (eds.) 2017. [Innovation fund: Impulses for the German healthcare system], Berlin: Medizinisch Wissenschaftliche Verlagsgesellschaft.

AUSCHRA, C. 2017. (No) Change towards Inter-Organizational Collaboration in Established Institutional Fields - Insights from German Health Care (Inaugral Dissertation). Doktorin der Wirtschaftwissenschaften, Freie Universität Berlin.

AUSCHRA, C. \& SYDOW, J. 2020. Path dependence and integrated care. In: AMELUNG, V., STEIN, V., GOODWIN, N., BALICER, R., NOLTE, E. \& SUTER, E. (eds.) Handbook Integrated Care. Berlin: Springer.

BLETTNER, M., DIERKS, M. L., DONNER-BANZHOFF, N., HERTRAMPF, K., KLUSEN, N., KOPKE, S., MASANNECK, M., PFAFF, H., RICHTER, R. \& SUNDMACHER, L. 2018. [Deliberations of the expert advisory council on innovation fund applications]. Z Evid Fortbild Qual Gesundhwes, 130, 42-48.

BUSSE, R., BLÜMEL, M., KNIEPS, F. \& BARNIGHAUSEN, T. 2017. Statutory health insurance in Germany: a health system shaped by 135 years of solidarity, self-governance, and competition. Lancet, 390, 882-897.

BUSSE, R. \& STAHL, J. 2014. Integrated care experiences and outcomes in Germany, the Netherlands, and England. Health Aff (Millwood), 33, 1549-58.

CHRISTENSEN, C. M., RAYNOR, M. \& MCDONALD, R. 2015. What is disruptive innovation? Harv Bus Rev, 93, 44-53.

DIE BUNDESREGIERUNG DER BUNDESREPUBLIK DEUTSCHLAND 2019. [Interim report on the scientific evaluation of the funding by the Innovation Fund with regard to its suitability for the further development of health care] Zwischenbericht über die wissenschaftliche Auswertung der Förderung durch den Innovationsfonds im Hinblick auf deren Eignung zur Weiterentwicklung der Versorgung. Deutscher Bundestag. Berlin: Deutscher Bundestag, 19. Wahlperiode.

GEMEINSAMER BUNDESAUSSCHUSS 2020a. [First projects completed - nomination round for the expert pool completed]. Berlin: Gemeinsamer Bundesausschuss,.

GEMEINSAMER BUNDESAUSSCHUSS. 2020b. [The Innovation Fund and the Innovation Committee of the Federal Joint Committee] [Online]. Berlin: Gemeinsamer Bundesausschuss. Available: https://innovationsfonds.g-ba.de/ [Accessed 17 Aug. 2020].

GERSCH, M., KREIS, H., REUTER, A. \& SCHRÖDER, S. 2012. [Monitoring Integrated care. Special forms of care: (No) growth in sight?] Monitoring Integrierte Versorgung. Besondere Versorgungsformen: (kein) Wachstum in Sicht? Berlin: Freie Universität Berlin.

GERSCH, M., KREIS, H., WESSEL, L., SCHRÖDER, S., RÜSICKE, T. \& MEROTH, L. 2010. [Monitoring IV. Results of a complete survey on the special forms of care for statutory health insurance funds] Monitoring-IV. Ergebnisse einer Vollerhebung $\mathrm{zu}$ den besonderen Versorgungsformen bei Gesetzlichen Krankenversicherungen. 7. Nationale Konferenz der Dt. Ges. für Integierte Versorgung e.V. Bonn.

GERSCH, M. \& SYDOW, J. 2017. [The Innovation Fund from the perspective of innovation research] In: AMELUNG, V. E., EBLE, S., HILDEBRANDT, H., KNIEPS, F., LÄGEL, R., OZEGOWSKI, S., SCHLENKER, R.-U. \& SJUTS, R. (eds.) Innovationsfonds: Impulse für das deutsche Gesundheitssystem. Berlin: Medizinisch Wissenschaftliche Verlagsgesellschaft. 
GIBIS, B. \& STEINER, S. 2014. [How does the new come into the (health) world? Opportunities and limitations of an innovation fund of the statutory health insurance] Wie kommt das Neue in die (Gesundheits-)Welt? Chancen und Limitationen eines Innovationsfonds der Gesetzlichen Krankenversicherung. Gesundheits- und Sozialpolitik, 20-25.

GILBERT, F., DENIS, J. L., LAMOTHE, L., BEAULIEU, M. D., D'AMOUR, D. \& GOUDREAU, J. 2015. Reforming primary healthcare: from public policy to organizational change. $J$ Health Organ Manag, 29, 92-110.

GÖCKLER, D. G. 2017. [The status of special forms of care according to SGB V and the corresponding potential of the Innovation Fund from the perspective of the statutory health insurance funds] Der Stand besonderer Versorgungsformen nach SGB V und entsprechende Potentiale des Innovationsfonds aus Sicht der gesetzlichen Krankenversicherungen. Master of Science Monography, „Alice-Salomon“ - Hochschule für Sozialarbeit und Sozialpädagogik Berlin, University of Applied Sciences.

GÖPFFARTH, D. \& HENKE, K. D. 2013. The German Central Health Fund-recent developments in health care financing in Germany. Health Policy, 109, 246-52.

GREB, S., FOCKE, A., HESSEL, F. \& WASEM, J. 2006. Financial incentives for disease management programmes and integrated care in German social health insurance. Health Policy, 78, 295-305.

KLEINKE, J. D., CHRISTENSEN, C. M., GROSSMAN, J. H. \& HWANG, J. 2009. The Innovator's Prescription: A Disruptive Solution for Health Care. Health Affairs, 28, 1223-1224.

KOCH, R., POLANC, A., HAUMANN, H., KIRTSCHIG, G., MARTUS, P., THIES, C., SUNDMACHER, L., GAA, C., WITKAMP, L., TELEDERM STUDY, G. \& JOOS, S. 2018. Improving cooperation between general practitioners and dermatologists via telemedicine: study protocol of the cluster-randomized controlled TeleDerm study. Trials, 19, 583.

KODNER, D. L. \& SPREEUWENBERG, C. 2002. Integrated care: meaning, logic, applications, and implications--a discussion paper. Int J Integr Care, 2, e12.

KUSS, K., SEIPP, H., BECKER, D., BOSNER, S., ERLER, A., GRUBER, D., HACH, M., ULRICH, L. R. \& HAASENRITTER, J. 2018. Study protocol: evaluation of specialized outpatient palliative care in the German state of Hesse (ELSAH study) - work package I: assessing the quality of care. BMC Palliat Care, 17, 111.

LLUCH, M. \& ABADIE, F. 2013. Exploring the role of ICT in the provision of integrated care-evidence from eight countries. Health Policy, 111, 1-13.

MILSTEIN, R. \& BLANKART, C. R. 2016. The Health Care Strengthening Act: The next level of integrated care in Germany. Health Policy, 120, 445-51.

MUR-VEEMAN, I., VAN RAAK, A. \& PAULUS, A. 2008. Comparing integrated care policy in Europe: does policy matter? Health Policy, 85, 172-83.

OBERMANN, K., MÜLLER, P., MÜLLER, H. H., SCHMIDT, B. \& GLAZINSKI, B. (eds.) 2019. Understanding the German Health Care System, Heidelberg: Mannheim Institute of Public Health (MIPH), Heidelberg University.

REINHARDT, D. 2018. [The Innovation Fund]. In: PFANNSTIEL, M. A., JAECKEL, R. \& DACRUZ, P. (eds.) Innovative Gesundheitsversorgung und Market Access. Beiträge für Entscheider und Akteure. Wiesbaden: Springer Gabler.

SCHLETTE, S., LISAC, M. \& BLUM, K. 2009. Integrated primary care in Germany: the road ahead. Int J Integr Care, 9, e14.

SCHMITT, J., PETZOLD, T., NELLESSEN-MARTENS, G. \& PFAFF, H. 2015. [Prioritization and Consentation of Criteria for the Appraisal, Funding and Evaluation of Projects from the German Innovationsfonds: A multi-perspective Delphi study]. Gesundheitswesen, 77, 570-9.

STEGMAIER, P. \& ROSKI, R. 2019. [The innovation of the Innovation Funds] Die Innovation des Innovationsfonds. Monitor Versorgungsforschung, 29-35.

SYDOW, J., SCHREYÖGG, G. \& KOCH, J. 2009. Organizational Path Dependence: Opening the Black Box. Academy of Management Review, 34, 689-709.

THOMSON, S., BUSSE, R., CRIVELLI, L., VAN DE VEN, W. \& VAN DE VOORDE, C. 2013. Statutory health insurance competition in Europe: a four-country comparison. Health Policy, $109,209-25$. 